\title{
Future Development Trends of REITs in Mainland China
}

\author{
Xiaoli $\mathrm{Ma}^{1 *}$ \\ ${ }^{1}$ University of York, York, YO10 5DD, UK
}

\begin{abstract}
REITs, as unconventional real estate financial tools, are considered to be the most advanced productivity representatives in the real estate industry. With the issuance of the "Notice on Promoting the Pilot Work of Real Estate Investment Trusts (REITs) in the Infrastructure Sector", the establishment of China's real estate investment trusts (REITs) market has become a frontier issue that academia, real estate and financial industries are most concerned about. This article mainly uses the comparison method to analyze the average return rate, FFO growth rate and dividend rate of US and Singapore REITs from 2019 to September 2020. The study found that: when the COVID-19 pandemic and the overall economic environment is unstable, all REITs have varying degrees of negative impact, especially for hotel REITs and retail REITs, the adverse impact is more serious, and the adverse impact on logistics REITs and digital computer room REITs is small. The results show that US and Singapore REITs can better resist risks by adopting the diversified portfolio theory. Based on the comparison of the performance of US and Singapore REITs, this study suggests the future of China: First, pay more attention to the central and western regions and third- and fourth-tier cities to achieve geographic diversification; second, pay attention to the bright future of logistics REITs and new infrastructure REITs.
\end{abstract}

\section{INTRODUCTION}

\subsection{Research status}

Real Estate Investment Trusts (REITs) is a kind of securitization of industrial funds in the real estate industry. Through the issuance of equity certificates, it gathers funds from an unspecified majority of investors from all walks of life, and is managed by professional investment institutions, using various Real estate projects, businesses, securities, etc. form an investment portfolio, and the investment income is distributed to investors proportionally in the form of dividends. In recent decades, scholars from various countries have conducted a lot of research on REITs and made important progress, but up to now, China lacks research on the development of REITs in third- and fourthtier cities and the central and western regions, as well as research on logistics REITs and new infrastructure REITs. To this end, this article analyzes the average income of US hotel REITs, commercial REITs, and the impact on these two REITs when the overall economic environment is unstable. In addition, the investment characteristics of US and Singapore REITs are also analyzed. Finally, based on the analysis results of the US and Singapore, as well as the current impact of COVID-19 on Chinese residents, suggestions for the future development of REITs in mainland China are given.

\subsection{The impact of COVID-19 on Chinese residents}

As of August 2020, COVID-19 has affected 213 countries and regions. Under the COVID-19 pandemic, people's focus has gradually shifted from fighting the epidemic to how to restore economic operations and production. The epidemic has affected Chinese people to varying degrees, such as Re-urbanization, home isolation, and online shopping.

Re-urbanization: Once, people, especially young people, were more willing to live and work in big cities. But when the epidemic broke out, people needed to stay at home for a long time, and the city instantly became a "prison", which made people discover the beauty of the urban living environment. With the improvement of transportation, network, and express delivery, the difference between people living in first- and second-tier cities and prefecture-level cities is becoming less and less obvious.

Online shopping: For many middle-aged and elderly people, before the outbreak, offline physical locations such as supermarkets, vegetable markets, and pharmacies were their mainstream lifestyle. However, because of the physical isolation necessary for the epidemic, many shopping can only be moved online. The online lifestyle is understood and accepted by more people, and it has even become a long-term habit.

As China has basically controlled the spread of the epidemic, all sectors of society have gradually returned to

\footnotetext{
* Corresponding author: bonniema12@163.com
} 
normal. In April 2020, the China Securities Regulatory Commission and the National Development and Reform Commission jointly issued the "Notice on Promoting the Pilot Work of Real Estate Investment Trust Funds (REITs) in the Infrastructure Sector". At present, China's REITs have only achieved formal equity, but not actual equity [1]. In addition, under the large framework of the domestic asset securitization system, China's REITs are more like a special "financing product", and they lack independent decision-making and operation capabilities (including fund expansion, property sales, loan financing, etc.) [2]. China's REITs are insufficient in function and form to become international REITs in the strict sense, so they are called "quasi REITs". The issuance of this notice means that Chinese REITs moving from private equity to public offering is the best way to increase the liquidity of the secondary market on a large scale [3] [4].

\section{DIVERSIFICATION OF REITS IN MATURE MARKETS}

\subsection{Geographical diversity}

2.1.1 US: REITs in the United States have many advantages over other investment products. The business of REITs in the United States continues to grow and prosper. As of the end of 2019, there were more than 900 REITs active in the world, of which the US market accounted for $65 \%$. US REITs have high returns and low risks, which is closely related to their investment diversification. At present, the property types of US REITs are very rich and scattered, including office buildings, industrial plants, industrial and commercial mixed types, shopping centers, regional shopping malls, self-service retail stores, apartments, prefabricated houses, logistics distribution, holiday centers, self-storage, Medical centers, etc.

At present, the development strategy of most companies will adopt diversification strategy as an important part of their main corporate strategy. As explained by the basic principles of modern portfolio theory, as long as the cash flows of various sectors are not completely correlated, the total risk of the overall business can be effectively reduced through diversification [5]. Therefore, successful REITs companies in the US actively use this principle, which is to expand multiple geographic regions and multiple different sub-REITs to achieve investment diversification.

After researching a number of diversified REITs in the US, it is found that these companies have shown the diversification of the geographical distribution of assets. These diversified REITs are all national real estate investment funds that can develop, construct, own and manage real estate industries throughout the US. All REITs reasonably diversify their investments in real estate types, locations and countries, and the amount of real estate investment according to their investment objectives and market conditions. For example, Vornado Realty Trust
(VNO) is a typical asset portfolio feature and business strategy of diversified REITs. There are four major divisions (New York Real Estate, Washington Real Estate, Retail Real Estate, and Commodity Market Real Estate), operating a variety of real estate including office, industrial, and retail with a rentable area of over 9.29 million square meters. In terms of geographical proportions, about $80 \%$ of the property area held by VNO is concentrated in the New York area. It is one of the main real estate owners in New York City. Other assets are distributed in cities such as San Francisco, Chicago, Georgetown and Miami. The company's assets are concentrated in Manhattan's main shopping streets and areas with the highest traffic: Fifth Avenue, Times Square, etc.

2.1.2 Singapore: After the Asian financial crisis in 1997, Singapore launched REITs to stabilize the financial market and economic situation, becoming the first country in Asia to issue REITs. Asia is the third most active market in REITs. As of the end of 2019, there were a total of 178 REITs active in the Asian market. Japan, Singapore, and Hong Kong were the top three REITs markets in Asia. By the end of 2019, there were 35 REITs, 6 stapled trusts and 2 property trusts listed on the SGX. The market value of Singapore's REITs has an average dividend yield of $6.2 \%$ in the past 10 years, ranking among the highest dividend yields in the world. The types of REITs in Singapore include office buildings, hotels and serviced apartments, retail, urban complexes, infrastructure, medical and industrial logistics.

The main strategy of Singapore REITs is to focus on a single area. Most commercial and industrial REITs acquire a certain property and take advantage of the local market. However, for some logistics and hotel (serviced apartment) REITs, it is crucial to adopt a geographically diversified portfolio strategy. For example, Mapletree Logistics Trust owned 15 warehouses and industrial properties in Singapore when it was founded in 2005. Since then, it has gradually developed into a pan-Asian logistics REITs in 7 different regional markets (Singapore, Malaysia, Hong Kong, China Mainland, Japan, South Korea, Vietnam) owns 111 real estates. In addition, Ascott Residences Trust is a serviced apartment REIT with a broad portfolio of properties in 36 cities in 13 countries in the Asia-Pacific region and Europe, including serviced apartments, rental properties and accommodation assets.

\subsection{Diversification of asset portfolio}

A diversified investment portfolio can help investors increase returns and diversify risks. For example, the housing/hotel industry and retailer district are very sensitive to the overall economic environment. When COVID-19 broke out in 2020, the REIT of global accommodation/hotels and retailer district had the greatest negative return impact. Due to the COVID-19 epidemic, almost all global travel is banned, and the ban on travel has a huge adverse impact on the hotel industry, for example, the FFO of some retailer district REITs and hotel REITs in 
the US showed varying degrees of negative growth (Table 2\&3).

As of April 2020, the operating profit of the US hotel industry fell by $116 \%$, and the real estate investment trust's loss-the accommodation real estate investment trust lost $45.81 \%$ [6].

Now, even though countries gradually loosen resident control measures and people begin to resume normal work and life, people are not willing to go to crowded places, and tourists are unwilling to travel and stay in hotels. As long as COVID-19 cannot be effectively controlled, commercial real estate will be in a dilemma of declining profitability for a long time. In addition, as early as 2018, research found that the growth of e-commerce and the development of online retail platforms [7]. Global Electronics Business sales have grown rapidly from USD 1.5 trillion in 2015 to USD 4.1 trillion in 2020, an increase of 2.7 times [8] [9] [10] [11] [12]. Industrial and logistics real estate investment trusts (I\&L REIT) have become an important part of the real estate investment field in the US. Goodman increased the logistics property risk in its real estate portfolio from $78 \%$ in 2007 to $94 \%$ in 2018 , while reducing the allocation of traditional industrial properties by $16 \%$ [13]. With the COVID-19 outbreak in 2020, countries have strictly implemented the system of home isolation, which has promoted the development of electronic commerce and online transactions.

Therefore, under the same market and economic environment, REITs in different fields have different returns and risks, which once again shows that asset portfolio diversification can help offset the risks of REITs in any sub-industry, and can help investors prevent a certain Significant fluctuations in the field of REITs.

TABLE 1. PROPERTY TYPES OF U.S. REITS: (SOURCE: NAREIT US REITS ASSOCIATION)

\begin{tabular}{|c|l|l|}
\hline Asset classes & $\begin{array}{c}\text { 2019Average } \\
\text { annual } \\
\text { return(\%) }\end{array}$ & $\begin{array}{c}\text { Jan-April 2020 } \\
\text { return (\%) }\end{array}$ \\
\hline Industry & 48.71 & -3.17 \\
\hline Office & 31.42 & -22.63 \\
\hline Retail & 10.65 & -41.16 \\
\hline Residential & 30.89 & -18.05 \\
\hline Hotel & 15.65 & -45.81 \\
\hline Medical & 21.20 & -30.42 \\
\hline Logistics & 13.70 & -14.15 \\
\hline Forest & 42.00 & -25.82 \\
\hline Infrastructure & 41.95 & 8.82 \\
\hline Specialty & 27.39 & -31.89 \\
\hline
\end{tabular}

TABLE 2. HOTEL REITS

\begin{tabular}{|c|l|l|}
\hline Title & $\begin{array}{c}\text { FFO Growth } \\
\text { Rate }\end{array}$ & Dividend Rate \\
\hline $\begin{array}{c}\text { Sotherly Hotels } \\
\text { Inc. }\end{array}$ & $-217.7 \%$ & $21.41 \%$ \\
\hline $\begin{array}{c}\text { Hospitality } \\
\text { Properties Trust }\end{array}$ & $-11.33 \%$ & $8.89 \%$ \\
\hline $\begin{array}{c}\text { RLJ Lodging } \\
\text { Trust }\end{array}$ & $-159.51 \%$ & $7.61 \%$ \\
\hline $\begin{array}{c}\text { Pebblebrook } \\
\text { Hotel Trust }\end{array}$ & $-167.68 \%$ & $6.15 \%$ \\
\hline $\begin{array}{c}\text { InnSuites } \\
\text { Hospitality Trust }\end{array}$ & $-190.97 \%$ & $1.82 \%$ \\
\hline
\end{tabular}

TABLE 3. RETAILER DISTRICT REITS

\begin{tabular}{|c|l|l|}
\hline Title & $\begin{array}{c}\text { FFO Growth } \\
\text { Rate }\end{array}$ & Dividend Rate \\
\hline $\begin{array}{c}\text { CBLd Associate } \\
\text { Properties }\end{array}$ & $-31.24 \%$ & $43.72 \%$ \\
\hline $\begin{array}{c}\text { Macerich } \\
\text { Company }\end{array}$ & $-43.44 \%$ & $22.36 \%$ \\
\hline $\begin{array}{c}\text { Cedar Realty } \\
\text { Trust }\end{array}$ & $-19.75 \%$ & $14.81 \%$ \\
\hline $\begin{array}{c}\text { Simon Property } \\
\text { Group }\end{array}$ & -36.63 & $11.70 \%$ \\
\hline $\begin{array}{c}\text { Urstadt Biddle } \\
\text { Properties Inc. } \\
\text { Class } \boldsymbol{A}\end{array}$ & $-23.38 \%$ & $9.80 \%$ \\
\hline $\begin{array}{c}\text { Kite Realty } \\
\text { Group Trust }\end{array}$ & $-23.40 \%$ & $9.10 \%$ \\
\hline Saul Centers & $-13.14 \%$ & $8.51 \%$ \\
\hline $\begin{array}{c}\text { Retail Properties } \\
\text { of America }\end{array}$ & $-5.34 \%$ & $8.22 \%$ \\
\hline $\begin{array}{c}\text { Kimco Realty } \\
\text { Corporation }\end{array}$ & $-32.27 \%$ & $7.96 \%$ \\
\hline $\begin{array}{c}\text { Spirit Realty } \\
\text { Capital }\end{array}$ & $-3.58 \%$ & $6.93 \%$ \\
\hline \multicolumn{2}{|c|}{} \\
\hline
\end{tabular}

\section{China deVelops REITs after COVID-19}

COVID-19 has a certain degree of impact on the living environment and lifestyle of Chinese people and these impacts will continue. Therefore, China needs to make adjustments and changes to develop REITs after COVID19.

\subsection{Geographical diversity}

Diversification of investment areas includes four situations (1) a combination of properties of the same type in different areas in the same city; (2) a combination of different types of properties in different areas in the same city; (3) a combination of properties of the same type in different cities; 4) The combination of different types of properties in different cities. As of September 30, 2019, China has issued a total of 58 REITs, and about $75 \%$ of the target properties of the products are single property assets in a certain area. However, only 14 products hold properties in different regions, which has achieved a certain degree of diversification in geographical distribution. For example, the first phase of the first phase of the asset-backed special plan of China United Qianhai Kaiyuan-Poly Real Estate Rental Housing No. 1 in Beijing and Chongqing, Dalian and other 9 cities have 10 residences, hotel apartments, office buildings; CITIC-Jinshi-Country Garden Phoenix Hotel asset support special plan, has 14 Country Garden hotel properties in 14 cities including Changsha [14].

After COVID-19, many urban residents are willing to return to their hometown to live and live in third-, fourth-, and fifth-tier cities due to their emotional needs and requirements for the living environment. And China is now vigorously developing central and western cities and small and medium-sized cities. Therefore, these underdeveloped central and western cities and regions are blue ocean markets for the development of REITs in the future. According to this change, the future development of REITs 
in China can be diversified from the following aspects. (1) Hotel real estate in central and western cities. China's abundant tourism resources and improved tourism conditions have made it increasingly attractive to domestic and foreign tourists. In particular, the consumption of tourism in the central and western regions has gradually matured, and tourism resources and supplies are also accelerating maturity. This will become increasingly attractive to the world and attract many tourists. Therefore, part of the hotel investment will likely shift from the eastern and southern regions to the central and western regions. With the further development of the Midwestern economy and the further development of tourism resources, the hotel industry in the Midwest will develop further, and these places will become the new and most promising growth areas for the Chinese hotel industry. (2) Commercial real estate in third, fourth and fifth tier cities. China has a large number of prefecture-level cities with a population of one million, and after the COVID-19 outbreak, more and more first-tier city residents look forward to returning to life in third- and fourth-tier cities. However, the commerce in these cities is still in the department store stage, and some initially ushered in the shopping center model. The residents here have a good economic, cultural, educational, and transportation infrastructure, and are backed by a huge population. More importantly, the consumption growth of residents in small and medium-sized cities is obvious and their consumption power is strong. The commercial development and attention of these cities is not high, and the future potential is urgently needed to be activated. Therefore, in the future, the target properties of China's REITs are not limited to first- and second-tier cities, and the central and western regions and small and medium-sized cities with large populations should not be ignored.

\subsection{Asset types diversity}

As of September 2019, nearly 75\% of REITs in China are subject to single property assets. For example, the target properties of the first-phase asset-backed special plan of China United Qianhai Kaiyuan-Poly Real Estate Rental Housing No. 1 are 10 residences, hotel apartments and office buildings; the target property of the 2017 assetbacked special plan of Suning Plaza is Lianyungang Suning Plaza. Sofitel Suning Hotel and Apartments. Research has found that US, Singapore and other countries have diversified target properties. One of the most noteworthy is the Logistics REITs, which are already independent sectors in US and Singapore. The storage industry is mainly based on holding operations, and its return period is long. Therefore, the industry needs to be combined with REITs to form a virtuous circle of capital operation. On April 30, 2020, the China Securities Regulatory Commission and the National Development and Reform Commission jointly issued relevant policies to promote the pilot project of real estate investment trust funds in the infrastructure sector. It is required to focus on key industries such as warehousing, logistics and toll roads, and encourage pilot projects such as new infrastructure, information networks. At present, more than $90 \%$ of warehouses in China are traditional warehouses, and the serious shortage of high-quality assets has become a shortcoming in the field of warehousing and logistics. Therefore, high-quality warehouses (such as high-standard warehouses) are important infrastructures that benefit from this policy and are also high-quality underlying assets. This type of warehouse has the characteristics of strong customer strength, long lease time, high space utilization, superior project site selection, advanced automation level, and strong compliance attributes, and fully meets the highquality asset requirements of REITs [15]. With the outbreak of COVID-19, a large number of offline transactions have moved online. With the formation of this type of shopping habits and the emergence of more and more high-quality e-commerce platforms in China, the scale of China's online shopping market will continue to expand. This trend has gradually increased the demand for warehouses. The mainstream e-commerce platforms Alibaba, JD.com, and Suning are all investing in highquality warehouse facilities. The release of this policy, the increase of high-quality e-commerce platforms, and the popularity of the Internet will rapidly expand e-commerce and online transactions. In addition, according to the FFO growth rate and dividend rate of US Logistics REITs and digital computer room REITs (Tables 4 \& 5), investors are reminded to pay more attention to and tap the bright prospects and potential of the warehousing industry and infrastructure.

TABLE 4. WAREHOUSE REITS

\begin{tabular}{|c|l|l|}
\hline Title & $\begin{array}{c}\text { FFO Growth } \\
\text { Rate }\end{array}$ & Dividend Rate \\
\hline $\begin{array}{c}\text { Global Self } \\
\text { Storage }\end{array}$ & $14.45 \%$ & $6.44 \%$ \\
\hline CubeSmart & $-1.73 \%$ & $4.06 \%$ \\
\hline Life Storage & $-1.04 \%$ & $3.87 \%$ \\
\hline $\begin{array}{c}\text { National Storage } \\
\text { Affiliates Trust }\end{array}$ & $9.49 \%$ & $3.79 \%$ \\
\hline Public Storage & $1.54 \%$ & $3.61 \%$ \\
\hline $\begin{array}{c}\text { Extra Space } \\
\text { Storage Inc. }\end{array}$ & $0.94 \%$ & $3.22 \%$ \\
\hline
\end{tabular}

TABLE 5. DIGITAL COMPUTER ROOM REITS

\begin{tabular}{|c|l|l|}
\hline Title & $\begin{array}{c}\text { FFO Growth } \\
\text { Rate }\end{array}$ & Dividend Rate \\
\hline $\begin{array}{c}\text { CoreSite Realty } \\
\text { Corporation }\end{array}$ & $7.41 \%$ & $4.24 \%$ \\
\hline $\begin{array}{c}\text { Digital Realty } \\
\text { Trust }\end{array}$ & $22.18 \%$ & $3.01 \%$ \\
\hline QTS Realty Trust & $21.91 \%$ & $2.89 \%$ \\
\hline CyrusOne & $19.65 \%$ & $2.66 \%$ \\
\hline Equinix & $8.09 \%$ & $1.4 \%$ \\
\hline
\end{tabular}

\section{Conclusion}

This article analyzes mature REITs in the US and Singapore and finds that hotel REITs and retail REITs suffer serious losses when the overall economic environment is unstable, while logistics REITs and digital computer room REITs suffer relatively small losses. In addition, research has found that the development of REITs 
in multiple regions and multiple fields can diversify risks and increase returns. At the end of this article, based on the analysis results of the US and Singapore, on the one hand, it summarizes the experience of successful REITs and provides effective suggestions for China to accelerate the construction of REITs in the future. On the other hand, it looks for suitable development strategies for China's REITs based on the current impact of COVID-19 on China.

\section{REFERENCES}

1. L. Liao, Y.H. Huang and Y. Su. (2003). The way to transform savings into funds for the construction of small and medium-sized cities and towns-The development and enlightenment of American real estate investment trusts (REITs)[J]. International Economic Review, 2003, (04): 24-28.

2. M.L. Fu and C.H. Xin (2018). The development and breakthrough of REITs in China's capital marketBased on the perspective of REITs micro-foundation and macro-environment[J]. Finance and Economics (Academic Edition), 2018, (17): 40-41.

3. G. Xiao. (2019). Five major factors restricting my country's public offering REITs and the cracking path[J]. Tsinghua Financial Review, 2019, (02): 62-6

4. G. Wang. (2019). The ever-calling public offering REITs in China[J]. Tsinghua Financial Review, 2019, (02): 69-70.

5. R. Amit \& J. Livnat. (1988). Diversification and the risk-return trade-off. Academy of Management Journal, 31(1), 154-166.

6. G. Jaehee and J. SooCheong. (2020). Lodging REITs and third-party operators: Do more operators enhance the performance of REITs? Tourism Management 2020.

7. KPMG (2018), The Truth about Online Consumers: 2017, KPMG, Amsterdam.

8. T. Bohjalian. (2018), Call the Market: Rate Reaction Opens REIT Opportunity, IPE Real Assets, London.

9. CBRE (2018a), 2018 Global Real Estate Market Outlook, CBRE, Los Angeles.

10. Knight Frank (2018), E-Commerce: All Just a Click Away: 2018, Knight Frank, London.

11. World Bank (2018), Connecting to Compete 2018: Trade Logistics in the Global Economy, World Bank, Washington, DC.

12. Chong, F. (2019a), Asia-Pacific: At the Epicentre of Logistics Transformation, IPE Real Assets, London.

13. Goodman (2018), Goodman Annual Report 2018, Goodman, Sydney.

14. M.Y. Meng. (2020). The U.S. Experience of Real Estate Trust Investment Funds. Economic and Management Review. 2020.36(01).

15. Z.J. Tian. (2019).Why is there a shortage of highstandard warehouses and vacant simple warehouses? Modern Logistics News A01 Edition. 